International Journal of Instruction e-ISSN: 1308-1470 • www.e-iji.net

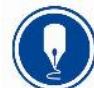

January $2022 \bullet$ Vol.15, No.1

p-ISSN: 1694-609X

pp. 799-820

Article submission code

20210214075517

Received: 14/02/2021

Revision: 09/08/2021
Accepted: 03/09/2021

OnlineFirst: 28/11/2021

\title{
The Evaluation of JIDI (Jigsaw Discovery) Learning Model in the Course of Qur'an Tafsir
}

Yuyun Affandi

Dr., UIN Walisongo Semarang, Indonesia yuyunaffandi@ walisongo.ac.id

\section{Agus Darmuki}

Muria Kudus University Kudus, Indonesia agus_darmuki@yahoo.co.id

\author{
Ahmad Hariyadi \\ Muria Kudus University, Indonesia ahmadhariyadi86@gmail.com
}

\begin{abstract}
This study aims 1) to develop JIDI learning model in the course of Qur'an tafsir; 2) to evaluate JIDI learning model in the course of Qur'an tafsir.The approach of study uses mixed method with a descriptive-evaluative and experiment research designs to evaluate the JIDI learning model in the course of Qur'an tafsir. The population of study are all first semester students of Islamic Communication \& Broadcasting Department, the Faculty of Da'wah and Communication at UIN Walisongo Semarang. The samples were class A to class $\mathrm{H}$ with amount 7 class first semester students. It uses stratified random sampling. Techniques in collecting data are questionnaire, interview, and test of Qur'an tafsir ability. The developing result of the learning model is carried out based on research about students' and lecturer's needs related to JIDI learning model. The evaluation of JIDI learning model is carried out based on the expert's assessment, the responses of lecturer and students, and suggestions from education practitioners until it is stated to be appropriate. The test result of Qur'an tafsir ability will be analyzed using t-test which has been tested for normality and homogeneity. Statistically, both Qur'an tafsir ability scores are different because $\mathrm{F}_{\text {calculation }}$ is 16.5875 while $\mathrm{F}_{\text {table }}$ is 3.91 at the significance level $=0.05$. Since $F_{\text {calculation }}>F_{\text {table }}$, it can be concluded that JIDI learning model gives significant influence in improving Qur'an tafsir ability. The implication of this study is that learning using JIDI model needs a long time, so it is suitable for the learning material with time allotment of eight meetings.
\end{abstract}

Keywords: JIDI learning model, Qur'an Tafsir, evaluation, development, learning

\section{INTRODUCTION}

Indonesia is a country with the largest moslem population in Asia (Lukman, 2016). The presence of Qur'an as a source of law in Islam has become a consensus of moslems as a miracle that provides guidance to the Prophet Muhammad SAW, it was revealed to be a lamp and guidance for humans in dealing with problems in their present and future lives

Citation: Affandi, Y., Darmuki, A., \& Hariyadi, A. (2022). The evaluation of JIDI (Jigsaw discovery) learning model in the course of Qur'an tafsir. International Journal of Instruction, 15(1), 799-820. https://doi.org/10.29333/iji.2022.15146a 
(Muhammad, 2017). Tafsir of the Qur'an becomes important knowledge that has to be mastered in order to understand the instructions and contents of Qur'an.

The phenomenon of interpreting Qur'an tafsir in Indonesia has emerged for a long time and has recently become an interesting issue among Indonesian moslems using various languages and media (Lukman, 2016; Muhammad, 2017; Nuralvi, 2018; Lukman, 2018). This phenomenon has also become an international issue in both moslem and non-moslem communities (Ogunnaike, 2018; Shabana, 2019; Saeed, 2019; Naguib, 2019). It has become interesting discussion subject for the experts on comparative religions and the world community. Based on the emergence of various models of Qur'an tafsir, it can be realized that tafsir is not static, sacred, and free of criticism. It has dynamics (Lukman, 2016: 167). The written works are often influenced by the dimensions of space and time, and the writer, because tafsir is an attempt to explain God's will based on the ability of the interpreter. Whether being realized or not, the explanation or interpretation cannot be separated from various interests, subjectivity, and the audience as the object.

The development of tafsir studies in Indonesia is relatively progressive and evolutionary. The learning of Qur'an tafsir finds its momentum from time to time and never stagnates, starting from its character, orientation, and nuance to the methodology and products (Nuralvi,2018). The emergence of Qur'an tafsir is not strictly tied to an era because everytime the Qur'an is read, studied, and interpreted in order to understand the God's instructions in it. Human's need for these instructions never stops, especially for things related to the needs of human life. Humans are always looking for these instructions. The more complex the problems of human life, the more intense human demands for the instructions of Qur'an. The Qur'an is considered as the source of religion in which it is always used to solve living problems.

The Qur'an tafsir learning is very important to be mastered to solve the problems of human life (Lukman, 2016). Lecturer of qur'an tafsir course has to really understand the needs of his students to learn Qur'an tafsir properly and correctly so that there are no multiple interpretation. The lecturer has to teach a complete concept with correct understanding in which the material is understood by all students completely and concretely with the same perception. To teach students with the same perception needs a learning model that is able to describe it by emphasizing study in groups and looking for the correct references with intensive lecturer assistance (Darmuki et.al., 2018: 116; Darmuki \& Hariyadi, 2019: 63; Darmuki \& Hidayati, 2019: 122).

Referring to Trianto (2018), the fact shows that the students memorize the concepts and principles, they are unable to implement it to solve the problems, they are not oriented to the constructivism learning so there are some learning problems. According to Sanjaya (2006), the problems in learning are the students' ability in discovering their own knowledge, in understanding their surrounding, and in enriching learning experience are low. The course of Qur'an Tafsir needs broader understanding, cooperation, collaboration, and application in the surroundings to obtain learning experiences. Therefore, it needs students' cooperation to solve a problem and think critically related 
to Qur'an tafsir. So, it can improve students' motivation, understanding, and learning outcomes.

All the time, the Qur'an tafsir learning is just about memorizing the concepts and principles without implementing and understanding it collaboratively. It has to be carried out to prevent wrong Qur'an interpretation. It can cause the deviation of Qur'an interpretation because the students' understandings have not achieved to the knowledge confirmation colaboratively.

The understanding of Qur'an tafsir learning requires creative and innovative learning models from the lecturer. The learning model is one of the determining factors for the success of student's learning process (Darmuki et.al., 2017: 45; Darmuki \& Hariyadi, 2019: 257; Darmuki \& Hidayati, 2019: 10; Putri et.al., 2020: 83) especially in the course of Qur'an tafsir. Learning model is an important communication tool for the lecturer to teach his students based on the learning objectives that want to be achievedb(Darmukiet.al., 2017). The development of learning model plays an important role in shaping students' characters. It is in line with Joyce, Weil \& Calhoun (2018: 9) that a school has various learning models are not only designed to achieve the scope of curriculum goals, but are also designed to help students increase their power as learners.

Nowadays, there are many learning models that have been designed by the learning experts, so that it really helps lecturer to maximize teaching and learning activities. Lecturers are not only required to use existing learning models, but they also have to be creative and innovative in collaborating various learning models based on the needs and maximizing the students' roles as learners so that they are able to develop their own abilities (Leung et.al., 2018).

Today's lecturers are expected to be able to adjust the learning models and collaborate it based on the students' need (Suryanti et. al., 2020: 76). The rationale for connecting various learning models is the differences or characteristics of students, in this case their intelligences and cognitive development, it is intended to maximize the students' potential ability optimally (Arifmiboy,2018). This is in accordance with the opinion of Arend (2018: 111) that there is no superior teaching model for all educational purposes. The lecturers need to adjust the learning model to meet student's neeed. They are not only required to implement existing learning models, but they also have to be creative and innovative in developing and collaborating learning models based on the needs of students (Dedono, 2016). The development of learning model emphasizes group learning (Şahin, 2010; Evcim \& Ipek, 2013; Şengül \& Katranci, 2014; Leyva \& Riu, 2016; Yemi et. al., 2018; Subiyantari et. al., 2019) and discovery learning through various references or sources (In'am \& Hajar, 2017; Martaida et.al., 2017; Nuryakin \& Riandi, 2017; Rahmadani et.al., 2017; Rambe et.al., 2018; Wardono et.al., 2020; Winarni et.al., 2020; Gunawan \& Lestari, 2020).

The jigsaw learning model is one type of group learning which consists of several members in a group who are responsible for mastering certain parts of learning materials and are able to teach it to other members in the group (Wilson et.al., 2017; Darmuki \& Hariyadi, 2019). In Jigsaw, each student becomes the member of home group and expert 
group (Şengül \& Katranci, 2014). The students in the expert group are responsible to master part of the materials which they must learn. They have the obligation to share it to the members in their home groups (Saputra et. al., 2019). Jigsaw learning model emphasizes the understanding of the same material in the expert group and share it to the home group (Ritonga \& Ruslan, 2017; Van Dat, 2016; Rachmah, 2017; Hoerunnisa et.al, 2017).

In Jigsaw learning, each member of the group gains a task, so they depend on each other to complete the task (interpersonal dependence). Jigsaw learning has several advantages such as individual competence is appreciated, creating class as learners community, students treat their classmates as learning resources, they trust each other and work together (Şengül \& Katranci, 2014). It increases the students' social competence, the ability to work in pairs, and their academic achievement (Van Dat, 2016; Rachmah, 2017). Jigsaw learning provides a cooperative learning situation which is able to improve students' activities (Hoerunnisa et.al, 2017).

The results of research by Yemi et.al. (2018) the weakness of Jigsaw learning is that it cannot be applied to all materials. The students with low academic ability have difficulties in understanding the materials because it needs high-order thinking skill (Darmuki \& Hariyadi, 2019). According to Darmuki et.al. (2018), the potential problem in Jigsaw learning is the students are able to master the materials; however they fail to teach it to their friends in home group. It makes other students in home group have less understanding.

In the discovery learning, the students are able to find knowledge from various valid sources and provide reinforcement through various references (Indiastuti, 2016). The discovery learning encourages students to determine their knowledge independently (Leung et.al., 2018). The students are active in finding problems, carrying out observations, collecting data, giving verification, and drawing conclusions. This learning is able to increase the students' understanding because they implement scientific methods in the learning process (Martaida et.al., 2017). Discovery learning refers to a learning environment in which the lecturer provides systematic guidance that focuses on learning goals (Kistneret. Al., 2016; Nurdiana et.al., 2018). The strengths of discovery learning are arousing students' curiosity, increasing learning motivation, and students memorize the materials in a longer time (Rambe et.al., 2018). The weakness of it is that it requires lecturer's creativity (In'am \& Hajar, 2017).

When discovery learning is used to align with jigsaw learning, the lecturer is able to help students to ask new problems from the material determined before class of after given an example (Hartini et. al., 2018). Through jigsaw and discovery learning models, it is supposed to build the same perception of materials as the discovery process through various valid sources and also be accompanied by lecturers. Tafsir Qur'an learning using jigsaw and discovery (JIDI) learning models is expected to provide a complete and correct concept of understanding.

The novelty of this study is on the development of JIDI learning model in which developed from Jigsaw model and discovery learning. It is collaborated to be JIDI 
learning model. This study has the potential to solve students' difficulties in collaborating. It is in contrast to the research findings by Suryanti et.al. (2020) and Saputra, et.al. (2019) in which students are difficult to built groupwork in jigsaw and discovery learning. It has been carried out in senior high school. Whether this study is carried out in the university. Moreover, the research method implemented by Suryanti et.al. (2020) and Saputra, et.al. (2019) is experimental research, and the references are books. Whether this study implements mix method, and the references are reputed journals. This study potentially improve students' learning achievements in cognitive, affective, and psychomotoric domains. It differs from a research by Rambe et.al. (2018) which is more focussed on cognitive domain.

The aims of this study is to (1) to develop JIDI learning model in the course of Qur'an tafsir; (2) to evaluate JIDI learning model in the course of Qur'an Tafsir conducted in Islamic Communication \& Broadcasting Department, the Faculty of Da'wah and Communication at UIN Walisongo Semarang

\section{METHOD}

\section{Participant}

This study was conducted in Islamic Communication \& Broadcasting Department, the Faculty of Da'wah and Communication at UIN Walisongo Semarang, with the basis of government Islamic college (Ministry of Religion). This study was conducted in this department because the course of Qur'an tafsir is a competence subject. Furthermore, UIN Walisongo Semarang is an Islamic-based public university of Indonesian religion ministry which hold fast to the Qur'an and Hadist.

\section{Procedure}

The approach of study uses mixed method with a descriptive-evaluative and experiment research designs to evaluate the JIDI learning model in the course of Qur'an tafsir. In this study, the bound variable is Qur'an Tafsir learning, the free variable is JIDI learning model. The researchers used research group design used by Fraenkel and Wallen (2018: 237), namely two groups of trials. One group served as the control group, and the other served as the experimental group. Both groups were given pre-test. The control group was treated using the learning model that had been used in the class. The experimental group was treated using JIDI learning model that had been developed. At the end of treatment, both groups were compared to measure the level of differences in their achievements. In addition, interview and questionnaire were used to find out the responses or suggestions of lecturers and students regarding the learning model that had been applied.

The procedure of developing JIDI learning model starts from the needs of students and teacher on JIDI learning model. Then, composing the draft of JIDI learning model, the draft is assessed by the experts, carrying out FGD, limited analyzing to obtain suggestions from lecturers, practitioners, and experts. Moreover, it is revised based on those suggestions until it is said to be appropriate as JIDI learning model. Furthermore, it is tested in a broader scale to investigate its effectiveness in the course of Qur'an Tafsir. 


\section{Population, Sample, and Sampling}

The population of this study were all first semester students who joined the course of Qur'an tafsir in Islamic Communication \& Broadcasting Department, UIN Walisongo Semarang. It consisted of 16 classes started from class A to class P. The samples were class A to class $\mathrm{H}$ with amount 7 class first semester students of Islamic Communication \& Broadcasting Department aged $17-24$ years old, 8 lecturers who worked full time for $6-11$ years. The students of class $A$ and class $C$ (group 1A) and class $E$ and class $G$ (group 2A) were used as the experimental group. The students of class B and class D (group 1B) and class $\mathrm{F}$ and class $\mathrm{H}$ (group 2B) as the control group in Islamic Communication \& Broadcasting Department with the number of students in each class $40-41$ students. The students of experimental group had a total of 81 students for each group, while the control group had a total of 80 students. It used stratified random sampling based on the qualification of class quality in Islamic Communication \& Broadcasting Department (high, medium, and low).

Stratified random sampling is a sampling technique in heterogeneous population by taking samples randomly from each sub-population in which the total number of it is adjusted with the total sub-population (Sugiyono, 2011). When the population is homogeneous, the samples can be taken from any population. When the population is heterogeneous, the samples have to represent every part of it so the result of study from the samples is fulfilled.

\section{Data Collection Technique}

\section{Questionnaire}

In developing the questionnaire, the researchers used relevant literature to review the JIDI (Jigsaw and Discovery) learning model. Based on the literature review, there are several criteria used to test the effectiveness of learning model. In order to obtain the validity and the questionnaire was not ambiguous, it would be examined by the experts of language and educational psychology. The questionnaire consisted of 10 items. Likert scale was used in it.

\section{Interview}

Interview was used to collect informations related to lecturers' perceptions on the effectiveness of JIDI learning model in the course of Qur'an tafsir. In addition, interviews were also used to obtain suggestions about JIDI learning model in the course of Qur'an tafsir. The interview were in forms of open-ended questions about evaluation, effectiveness, and learning objectives desired by the lecturers, and suggestions on improving JIDI learning model in the course of Qur'an tafsir. The respondents that were interviewed consisted of 8 lecturers and 20 students from 4 classes ( 5 heterogeneous students were chosen for each class).

\section{Test}

Test was used to determine the effectiveness or differences between Qur'an tafsir before and after using JIDI learning model. 


\section{Focus Group Discussion (FGD)}

The implementation of JIDI learning model in the course of Qur'an tafsir aimed to evaluate. The next step was spreading questionnaires, having interview, test of Qur'an tafsir, and FGD. FGD involved the experts in developing learning model consisted of one lecturer from UIN Walisongo, lecturers in the course of Qur'an tafsir, students involved in the sample, and the researchers. This activity was to determine the advantages and disadvantages of JIDI learning model.

\section{Data Analysis}

Technique of data analysis was triangulation mix-method design (mixed quantitative and qualitative research methods) with embeded type by simultaneously analyzing quantitative and qualitative data, and combined data (Sugiyono, 2011:46). The reason of using mix-method is because the research problems needs several data which is contextual and actual. It means that the researchers need various data using qualitative method as primary data that contains results of interview and questionnaire. The quantitative method as secondary data to test the hypothesis analysis of qualitative data. In line with Sugiyono (2011) who explains that mixed method collaborates qualitative and quantitative approaches, presents directly the relationships of researchers and respondents. The mixed method is utilized as empirical evidence in answering the research problems. The consequence is that the use of mix method causes the research findings are better, complete, and comprehensive.

Furthermore, the results of analysis were used to understand the research problem. In this case, quantitative data provided the way to generalize, while the qualitative data provided informations about context and setting. The quantitative test was carried out by statistical t-test. The researchers used SPPS program to obtain fast and accurate data calculations. The qualitative descriptive analysis was carried out on validation sheets and observation sheets at the implementation stage of JIDI learning model to improve students' ability to learn Qur'an tafsir. In addition, the qualitative analysis was also used to describe the students' learning outcomes when JIDI learning model was implemented. The process of data triangulation analysis was used source and theory triangulation, then carried out by analyzing both qualitative and quantitative data separately. Then, comparing the results and interpreting whether the data support or contradict each other.

\section{Data Validity}

The validity of data in this study uses the strategy of concurrent triangulation. According to Creswell (2013: 320), in this strategy the researchers collect data concurrently (in the same time), then they compare the data to know whether there are convergence, differences, or several combinations. In this strategy, there is mixing of qualitative and quantitative data when the study is in the stage of interpretation and discussion. The mixing is carried out by merging both research data or integrating or comparing the results of both data in discussion.

\section{Validation of Data Accuracy}

The assessment of critical thinking skill used test method in forms of essay tests. The instruments that would be used to gain data had to be tested first. The instrument 
feasibility test was carried out in two steps, namely validity and reliability test. It was done to find out the quality level of the test items. Validity was an important quality of each test. It was the accuracy and accuracy of an instrument in carrying out its function (Sugiyono, 2011). Valid meant that the instrument could be used to measure. The validity test was testing the instrument whether it was in accordance with the philosophy of science material provided by the lecturer. It was divided into two kinds, namely internal and external validity.

Before the questions were used to obtain the research data, the validity and reliability were tested. In testing validity, if $r$ count $>r$ table, the questions were valid. On the other hand, if $r$ count $<r$ table, the questions were invalid (Sugiyono, 2011). The result of instrument validity was shown in table 1 .

Table 1

Instrument validity

\begin{tabular}{lccl}
\hline Number of question & r count & r table & Conclusion \\
\hline 1 & 0.3136 & 0.3120 & Valid \\
\hline 2 & 0.3136 & 0.3120 & Valid \\
\hline 3 & 0.3136 & 0.3120 & Valid \\
\hline 4 & 0.3136 & 0.3120 & Valid \\
\hline 6 & 0.3136 & 0.3120 & Valid \\
\hline 7 & 0.3136 & 0.3120 & Valid \\
\hline 8 & 0.3136 & 0.3120 & Valid \\
\hline 9 & 0.3136 & 0.3120 & Valid \\
\hline 10 & 0.3136 & 0.3120 & Valid \\
\hline 11 & 0.3023 & 0.3120 & Invalid \\
\hline 12 & 0.3136 & 0.3120 & Valid \\
\hline 13 & 0.3023 & 0.3120 & Invalid \\
\hline
\end{tabular}

Table 1 showed there were 10 valid questions and 3 invalid questions. The questions were valid because $r$ count $>r$ table. The invalid questions was because $r$ count $<r$ table.

The next step examined the t-table in the significance level $(\alpha)$ of 0,05 and degree of freedom $(\mathrm{dk}=\mathrm{N}-2)$. The test decisions were as follows: when tcount $<$ ttable, the item was not valid, and when tcount $>$ ttable, the item was valid.

In testing reliability, when the value of Cronbach's Alpha $>0,60$, the questionnaire was reliable or consistent. When the value of Cronbach's Alpha $<0,60$, the questionnaire was not reliable or not consistent. The result of reliability test could be viewed in table 2.

Table 2

Reliability testing

\begin{tabular}{llll}
\hline Cronbach's Alpha & $\begin{array}{l}\text { Value of Cronbach's Alpha } \\
\text { Based on Standardized Items }\end{array}$ & Number of Items & Conclusion \\
\hline 0.64 & 0.60 & 10 & Reliable \\
\hline
\end{tabular}

Table 2 showed the value of Cronbach's Alpha $(0,64)$ was higher than 0,60 . The value of Cronbach's Alpha was based on standardized items, so it was concluded that the items were reliable. 


\section{Normality and Homogeneity Test Results}

The normality test in this study consisted of 8 sample groups. Each group consisted of 45 students. The sample group of class $1 \mathrm{~A}$ and $2 \mathrm{~A}$ consisted of four teams. In the calculation, the value of Asymp Sig was greater than the confidence level $\alpha=0,05$. It can be said that sample group came from a normally distributed population. The summary of normality test results could be viewed in table 3 .

Table 3

The summary of students normality test in class $1 \mathrm{~A}$

\begin{tabular}{lllll}
\hline No & Group & Value of Asymp Sig & Level of Reliance & Decision \\
\hline 1 & 1A & 0.135 & 0.05 & Normal \\
\hline 2 & 2A & 0.167 & 0.05 & Normal \\
\hline 3 & 1B & 0.171 & 0.05 & Normal \\
\hline 4 & 2B & 0.256 & 0.05 & Normal \\
\hline Explanations : & & \\
& 1A & : Experimental group of class 1A (Pretest) & \\
& 2A & : Experimental group of class 1A (Posttest) & \\
1B & : Control group of class 1B (Pretest) & \\
2B & : Control group of class 1B (Posttest)
\end{tabular}

In table 3, the value of Asymp Sig was higher than level of reliance $(0,05)$. It could be concluded that in Class 1A, the sample came from normally distributed population.

Tabel 4

The summary of students normality test in class A2

\begin{tabular}{rrlll}
\hline No & Group & Value of Asymp Sig & Level of Reliance & Decision \\
\hline 1 & 1A & 0.182 & 0.05 & Normal \\
\hline 2 & 2A & 0.128 & 0.05 & Normal \\
\hline 3 & 1B & 0.182 & 0.05 & Normal \\
\hline 4 & 2B & 0.281 & 0.05 & Normal \\
\hline Explanations : & & \\
& 1A & $:$ Experimental group of class 2A (Pretest) & \\
2A & $:$ Experimental group of class 2A (Posttest) & \\
1B & $:$ Control group of class 2B (Pretest) & \\
2B & $:$ Control group of class 2B (Posttest)
\end{tabular}

In table 4, the value of Asymp Sig was higher than level of reliance $(0,05)$. It could be concluded that in Class $2 \mathrm{~A}$, the sample came from normally distributed population.

Based on the homogeneity test of variant population, the test results were obtained as described in table 5.

Table 5

The summary of homogeneity test result

\begin{tabular}{llllll}
\hline No & Group & df & Value of Sig & Level of Reliance & Decision \\
\hline 1 & 1A & 160 & 0.728 & 0.05 & Homogeneous \\
\hline 2 & 1B & 160 & 0.743 & 0.05 & Homogeneous \\
\hline 3 & 2A & 159 & 0.756 & 0.05 & Homogeneous \\
\hline 4 & 2B & 159 & 0.662 & 0.05 & Homogeneous \\
\hline Explanations: & & & &
\end{tabular}

$1 \mathrm{~A}:$ Experimental group of class $1 \mathrm{~A}$ 


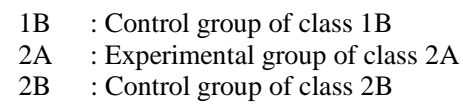

From the summary of homogeneity test results in table 5, it was clear that the value of sig was greater than 0,05 . It showed that the variances of population were homogeneous.

\section{FINDINGS}

The data collection begins with the analysis of lecturers' and students' needs by examining the curriculum documents, the completeness of learning tools made by the lecturers, and data analysis on the students' learning outcomes in the course of Qur'an tafsir. The result of study, that had been done previously, can be viewed in table 6 .

Table 6

Data collection instruments

\begin{tabular}{|c|c|c|c|}
\hline Stage & Data Recorded & Instrument & Response \\
\hline $\begin{array}{l}\text { Need } \\
\text { Analysis }\end{array}$ & $\begin{array}{l}\text { - The stucture and content of } \\
\text { lecturer's lesson plan } \\
\text { - The implementation of lecturer's } \\
\text { lesson plan } \\
\text { - Curriculum analysis } \\
\text { - Analysis of students' learning } \\
\text { outcomes in the course of Qur'an } \\
\text { tafsir }\end{array}$ & $\begin{array}{l}\text { - Assessment sheet of } \\
\text { structure and content } \\
\text { of lesson plan } \\
\text { - Observation sheet } \\
\text { - Interview sheet } \\
\text { - Students' learning } \\
\text { outcomes } \\
\text { - Assessment sheet }\end{array}$ & $\begin{array}{l}\text { Lecturer } \\
\text { Head of department } \\
\text { Lecturer } \\
\text { Lecturer }\end{array}$ \\
\hline \multicolumn{4}{|l|}{ Trial } \\
\hline a. Expert & $\begin{array}{l}\text { Validity of learning model and its } \\
\text { tools }\end{array}$ & - Validation sheet & $\begin{array}{l}\text { - educational expert, } \\
\text { - the expert in developing } \\
\text { learning model }\end{array}$ \\
\hline $\begin{array}{l}\text { b. Small } \\
\text { group test of } \\
\text { user }\end{array}$ & $\begin{array}{l}\text { Critics and suggestion about the } \\
\text { implementation of model and } \\
\text { readability of evaluation instrument }\end{array}$ & Open questionnaire & Lecturer and students \\
\hline c. Field test & $\begin{array}{l}\text { The implementation of learning } \\
\text { syntax Students' responses } \\
\text { Social interaction Learning } \\
\text { outcomes }\end{array}$ & $\begin{array}{l}\text { Observation sheet } \\
\text { Questionnaire } \\
\text { Questionnaire } \\
\text { Test }\end{array}$ & $\begin{array}{l}\text { Observation } \\
\text { Students } \\
\text { Students } \\
\text { Students } \\
\end{array}$ \\
\hline
\end{tabular}

The process of designing the development of JIDI learning model is carried out by collaborating the syntax of Jigsaw and discovery learning. There are four learning syntax of jigsaw, namely introduction, focussed exploration, reporting and re-arranging, integration and evaluation. There are six stages in the syntax of discovery learning, namely stimulation, problem identification, data collection, data processing, verification, and generalisation. The development of JIDI (Jigsaw Discovery) learning model in the course of Qur'an tafsir has been developed based on the needs of lecturers and students in the Islamic Communication \& Broadcasting Department. The process in designing JIDI learning model is carried out by combining the syntax of Jigsaw and discovery learning. It aims to make students gain multiple benefits from both learning models. Jigsaw learning is dominant with collaboration, and it trains students to have discussion and presentation abilities. The discovery learning requires scientific work, and it trains 
students to carry out observation, experiment, or another investigative activities. Each of these learning models has characteristics and strengths. When it is combined, the students will get more benefits.

When the draft of model has been finished, it is assessed by 2 experts, they are the experts of learning model and language. They have to validate the draft of JIDI learning model. The evaluation of it includes lesson plans, observation sheets, learning materials, assessment, and research instruments. The aspects of assessment are the feasibility of JIDI model and learning tools. The assessment results of research instruments by the experts can be viewed in table 7 .

Table 7

The validation results of learning model and tools by expert

\begin{tabular}{llll}
\hline No & Product Assessed & Value & Criteria \\
\hline 1 & JIDI Learning Model & 3.33 & Very Good \\
\hline 2 & Lesson Plans/Syllabus & 3.60 & Very Good \\
\hline 3 & Learning Material & 3.45 & Good \\
\hline 4 & Assessment & 3.44 & Good \\
\hline 5 & Research Instruments & 3.38 & Good \\
\hline Average & score & 3.44 & Good \\
\hline
\end{tabular}

Based on table 7, it can be stated that the validation is generally categorized as 'good' because the average value is 3.44 .

The revision draft of JIDI learning model is obtained from the experts, students, lecturers, and suggestions on FGD. It has been revised before limited-scale test. Moreover, it has to be changed based on the implementation in the class. There are some suggestions from the students and lecturers based on classroom observations. When it has been revised, the effectiveness test will be carried out.

There are four stages in Jigsaw learning syntax, namely introduction, focused exploration, report and rearrangement, integration and evaluation. The six stages of discovery learning syntax are stimulation, problem identification, data collection, data processing, verification, and generalization. The collaboration of both learning models combines the discovery activities into Jigsaw syntax. It results in the formation of new syntax, namely the syntax of JIDI learning model. The description of it can be viewed in table 8.

Table 8

The learning of Qur'an tafsir with JIDI learning model that has been developed

\begin{tabular}{|c|c|c|}
\hline No & Learning Stages & Description \\
\hline A & Opening & $\begin{array}{l}\text { a) Greeting and praying } \\
\text { b) Understand students' readiness } \\
\text { c) Connecting students' understanding and the learning material } \\
\text { d) Motivating students about the advantage and relevance of Qur'an tafsir } \\
\text { in their lifes (basic theory of meaningful learning by Ausebel) }\end{array}$ \\
\hline B & $\begin{array}{l}\text { Main Activity (Syntax } \\
\text { of JIDI) }\end{array}$ & \\
\hline & 1. Stimulation & $\begin{array}{l}\text { a) building students' interest and curiosity } \\
\text { b) Delivering the materials using videos and guessing the meaning of a }\end{array}$ \\
\hline
\end{tabular}




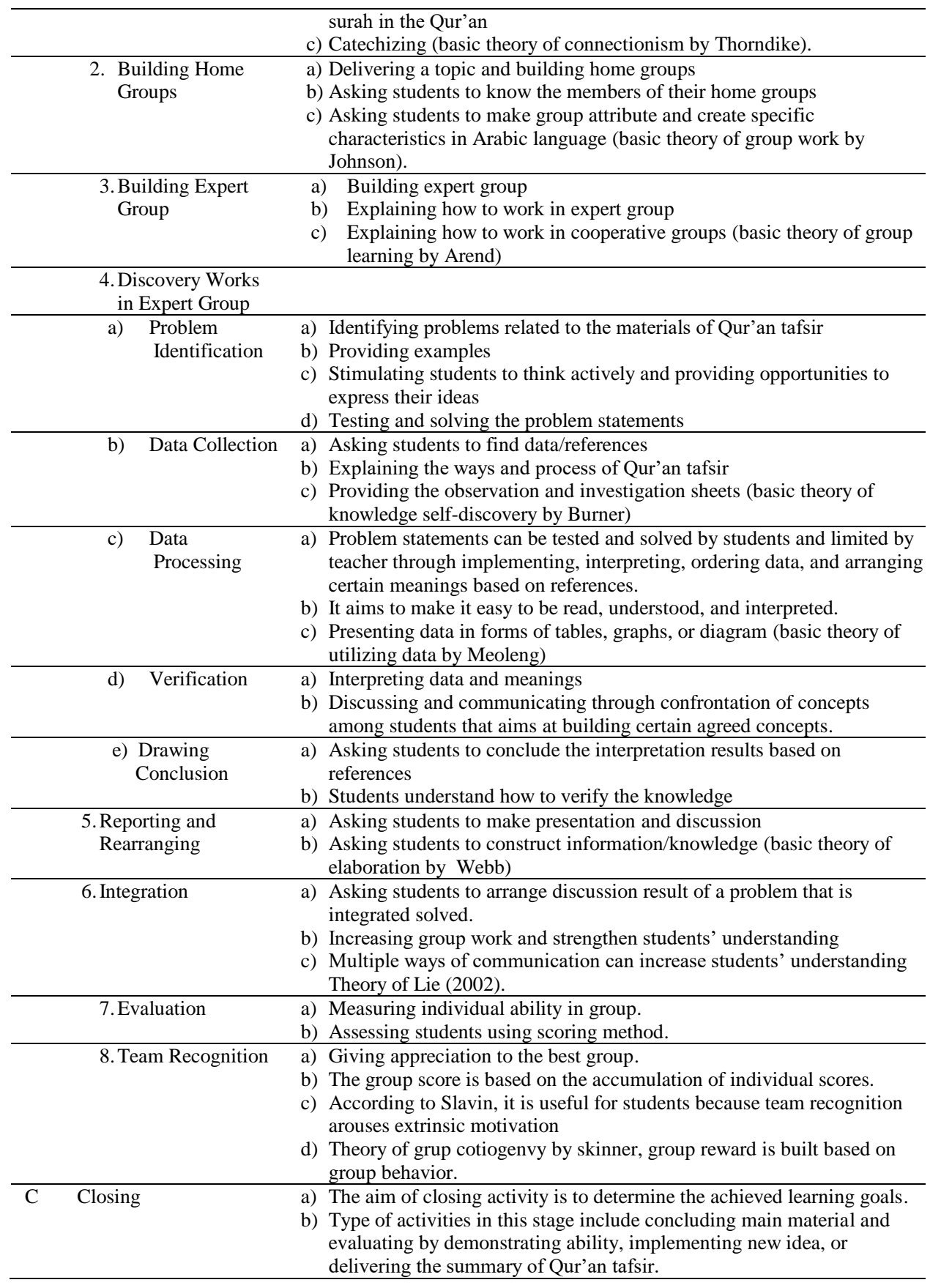

International Journal of Instruction, January 2022 •Vol.15, No.1 
Table 8 showed that the syntax of JIDI learning model consisted of three learning phases, namely opening, main activity, and closing. In the opening, students were motivated. In the main activity, there was a collaboration between syntax of jigsaw and syntax of discovery learning. In the closing, it determined the achievement level of learning objectives and conveyed the summary of learning materials.

The draft of JIDI learning model that had been developed is then validated by the experts of learning model and educational experts to obtain suggestions. These suggestions were used to revise the draft of JIDI. Furthermore, FGD was carried out to determine its strengths and weaknesses, also suggestions from the lecturers and policy makers. The suggestions were used to improve the JIDI learning model before being implemented and to investigate the effectiveness level of it.

To find out the effectiveness level of JIDI learning model, a study had been carried out. It was carried out in 8 class, namely class A to class $\mathrm{H}$, (1) for the experimental groups, namely class $A$, class $C$ (group $1 \mathrm{~A}$ ), class $\mathrm{E}$ and class $\mathrm{G}$ (group $2 \mathrm{~A}$ ); and (2) for the control group namely class B and class D (group 1B), class F and class H (group 2B).

This study was conducted on September 2019 to February 2020. It was carried out by involving 2 lecturers of class $\mathrm{A}$ and class $\mathrm{C}$ (group 1A) and 2 lecturers of class $\mathrm{E}$ and class $\mathrm{G}$ (group 2A). The control group also involved 2 lecturers of class B and class D (group 1B), and 2 lecturers of class $\mathrm{F}$ and class $\mathrm{H}$ (group 2B). The lecturers did a study on the learning of Qur'an tafsir using JIDI learning model based on the bookdraft of the implementation guide of JIDI learning for the students in the Islamic Communication \& Broadcasting Department. Before conducting this study, both the experimental and control groups were given pretest and posttest about the ability to interpret the Qur'an. The results of pretest and posttest were then tested for normality and homogeneity.

Therefore, it could be concluded that the variance of population was homogeneous. Furthermore, the descriptive results of pretest and posttest in class $1 \mathrm{~A}$ were shown in table 9.

Table 9

Ability to interpret Qur'an_1A and 2A_experimental group_pretest and posttest

\begin{tabular}{|c|c|c|c|c|c|c|c|c|}
\hline \multirow[t]{2}{*}{ 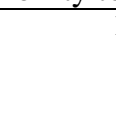 } & \multirow[t]{2}{*}{$\mathrm{N}$} & \multirow[t]{2}{*}{ Mean } & \multirow[t]{2}{*}{$\begin{array}{l}\text { Std } \\
\text { Deviation }\end{array}$} & \multirow[t]{2}{*}{ Std Error } & \multicolumn{2}{|c|}{$\begin{array}{l}95 \% \text { confidence } \\
\text { interval for mean }\end{array}$} & \multirow[t]{2}{*}{ Minimum } & \multirow[t]{2}{*}{ Maximum } \\
\hline & & & & & $\begin{array}{l}\text { Lower } \\
\text { Bound }\end{array}$ & $\begin{array}{l}\text { Upper } \\
\text { Bound }\end{array}$ & & \\
\hline $\begin{array}{l}\text { Pretest } \\
1 \mathrm{~A}\end{array}$ & 81 & 13.7531 & 2.23903 & .24878 & 13.2580 & 14.2482 & 9.00 & 18.00 \\
\hline $\begin{array}{l}\text { Posttest } \\
1 \mathrm{~A}\end{array}$ & 81 & 16.3210 & 2.07260 & .23029 & 15.8627 & 16.7793 & 12.00 & 20.00 \\
\hline $\begin{array}{l}\text { Total } \\
1 \mathrm{~A}\end{array}$ & 162 & 15.0370 & 2.50686 & .19696 & 14.6481 & 15.4260 & 9.00 & 20.00 \\
\hline $\begin{array}{l}\text { Pretest } \\
2 \mathrm{~A} \\
\end{array}$ & 80 & 16.4500 & 2.92480 & .32700 & 15.7991 & 17.1009 & 12.00 & 22.00 \\
\hline $\begin{array}{l}\text { Posttest } \\
2 \mathrm{~A}\end{array}$ & 80 & 18.9875 & 2.85734 & .31946 & 18.3516 & 19.6234 & 15.00 & 24.00 \\
\hline $\begin{array}{l}\text { Total } \\
2 \mathrm{~A} \\
\end{array}$ & 160 & 17.7188 & 3.15067 & .24908 & 17.2268 & 18.2107 & 10.00 & 23.00 \\
\hline
\end{tabular}


Table 10

Ability to interpret Qur'an_1B and 2B_control group_pretest and posttest

\begin{tabular}{|c|c|c|c|c|c|c|c|c|}
\hline \multirow[t]{2}{*}{ 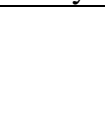 } & \multirow[t]{2}{*}{$\mathrm{N}$} & \multirow[t]{2}{*}{ Mean } & \multirow[t]{2}{*}{$\begin{array}{l}\text { Std } \\
\text { Deviation }\end{array}$} & \multirow[t]{2}{*}{ Std Error } & \multicolumn{2}{|c|}{$\begin{array}{l}95 \% \text { confidence } \\
\text { interval for mean }\end{array}$} & \multirow[t]{2}{*}{ Minimum } & \multirow[t]{2}{*}{ Maximum } \\
\hline & & & & & Lower & Upper & & \\
\hline $\begin{array}{l}\text { Pretest } \\
1 \mathrm{~B}\end{array}$ & 81 & 15.2514 & 2.46521 & .27513 & 12.4808 & 13.6200 & 7.00 & 17.00 \\
\hline $\begin{array}{l}\text { Posttest } \\
\text { 1B }\end{array}$ & 81 & 15.6545 & 2.02355 & .22607 & 14.1823 & 15.1263 & 10.00 & 19.00 \\
\hline $\begin{array}{l}\text { Total } \\
1 \mathrm{~B} \\
\end{array}$ & 162 & 13.8521 & 2.38084 & .18468 & 13.4652 & 14.2385 & 7.00 & 19.00 \\
\hline Pretest & 80 & 16.8361 & 2.81251 & .32461 & 16.1678 & 15.2622 & 12.00 & 20.00 \\
\hline Posttest & 80 & 18.5612 & 2.81854 & .32506 & 17.7121 & 17.1861 & 13.00 & 22.00 \\
\hline Total & 160 & 17.6986 & 3.13383 & .23897 & 15.1244 & 16.1484 & 10.00 & 22.00 \\
\hline
\end{tabular}

Table 9 and table 10 showed that students' pretest and posttest in experimental class (using JIDI learning model) were higher than control class (using lecturing method). In other words, the students of experimental class had higher learning achievement in the course of Qur'an tafsir than the students of control class.

The results of questionnaire that had been distributed to the lecturers could be viewed in table 11.

Table 11

Questionnaire for lecturer's perceptions

\begin{tabular}{llllll}
\hline No Items & Initial & & End & \\
\cline { 3 - 6 } & & Exp (\%) & Control (\%) & Exp (\%) & Control (\%) \\
\hline 1 & $\begin{array}{l}\text { Learning Qur'an tafsir is very } \\
\text { important }\end{array}$ & 55 & 75 & 100 & 100 \\
\hline 2 & $\begin{array}{l}\text { Delivering materials of Qur'an tafsir } \\
\text { in the class is very easy }\end{array}$ & 52 & 52 & 91 & 80 \\
\hline 3 & $\begin{array}{l}\text { The materials of Qur'an tafsir is } \\
\text { sufficient to be taught with personal } \\
\text { instructions in the class }\end{array}$ & 52 & 32 & 0 & 31 \\
\hline 4 & $\begin{array}{l}\text { Learning using JIDI learning model } \\
\text { consumes so much time. }\end{array}$ & 74 & 51 & 0 & 21 \\
\hline 5 & $\begin{array}{l}\text { I want to apply JIDI learning model } \\
\text { I understand the learning process in } \\
\text { using JIDI in the class }\end{array}$ & 100 & 100 & 100 & 71 \\
\hline 7 & $\begin{array}{l}\text { I understand the learning evaluation of } \\
\text { Qur'an tafsir using JIDI learning } \\
\text { model }\end{array}$ & 23 & 51 & 98 & 91 \\
\hline
\end{tabular}

The results of students' responses on JIDI learning model which is implemented in the classroom learning are in forms of interview. The result of it reveals that learning using JIDI model is fun and attractive because there is the presentation stage that is challenging. The results of interview with the lecturer showed that he was enthusiastic in teaching using JIDI learning model because the students were active in the class. He could control the groups, so it helped him in managing better learning. Based on the results of classroom observation, JIDI learning model caused the learning process was more active and in line with the objective of learning. It also showed that JIDI learning 
model drove students to interact with their groups, so it improved the social relationship and obtained maximal learning achievement. Furthermore, the students construct their own knowledge in their learning experiences. They are more active and creative in learning. It is different with the lecturing method which is boring. Learning using JIDI model drives students to have more concrete and complete understanding. Their interpretation about Qur'an are intact based on the theory or the problems faced and its implementation in the society life.

\section{DISCUSSION}

The comparison between JIDI learning model and conventional learning model (lecturing) shows a significant difference. It can be viewed from the learning outcomes of control class and experimental class. The learning outcome of experimental class (using JIDI learning model) is better than the control class (using lecturing method).

The test results of ability to interpret the Qur'an which were analyzed using t-test, had previously been tested for its normality and homogeneity. Statistically, both Qur'an tafsir ability scores were different because $F_{\text {calculation was }} 16.5875$ while $F_{\text {table }}$ was 3.91 at the significance level $=0.05$. Since $F_{\text {calculation }}>F_{\text {table, }}$, it could be concluded that JIDI learning gave significant influence in improving srudents' ability in Qur'an tafsir at the Islamic Communication \& Broadcasting Department. The result of this study revealed that JIDI learning model influenced on the improvement of learning achievement and social interaction in the learning of Qur'an Tafsir.

Based on the findings, the lecturer need to adjust students' learning needs with the learning strategies. Multiple models of instruction is the practice in implementing several different learning models in the teaching process. The selection of learning model depends on the characteristics of the learning materials and goal, its ability to meet students' needs, and its ability to increase students' learning capacity (Arifmiboy,2018). In line with Arend (2018: 111) who states that it is impossible to have one learning model that is considered to be the best for all educational purposes. In fact, every learning model is often suitable for certain types of learning. However, these learning models can be combined to help students to achieve the learning goals (Suryanti et. al., 2020: 76). There is no single approach is consistently better than another one.

The implementation of Jidi learning model is a combination of jigsaw and discovery learning, so several previous studies related to its learning outcomes can be used as a reference. The results of previous researchs show that students' learning outcomes with jigsaw are better than traditional learning (lecturing) in increasing their academic achievement (Sahin, 2010; Evcim \& Ipek, 2013; Wilson et.al., 2017; Hoerunnisa et.al., 2017; Subiyantari et.al., 2019). A study on the effectiveness of learning outcomes concludes that cooperative learning has the most positive influence on the students' achievement (Darmuki, et al., 2017).

The findings of JIDI model are also supported by the results of study on discovery learning. It shows that there are significant differences between the experimental group and control group related to academic achievement, retention scores, and 
students' perception of investigative skill at coginitive and affective levels (Dedonno, 2016; Indiastutik, 2016; Martaida et.al., 2017; Putri et.al., 2020; Gunawan et.al., 2020; Wardono et.al., 2020; Suryanti et.al., 2020). Another research reveals that discovery learning is better than traditional one viewed from students' academic achievement (Nuryakin \& Riandi, 2017). The students have better achievement in understanding the materials through discovery rather than lecturing method (Rahmadani et.al., 2017; Rambe et.al. 2018).

These findings are potentially increase students' social interaction in learning the course of Qur'an tafsir. The social interaction is important because of students' different characteristics in the class (Darmuki \& Hariyadi, 2019). The use of JIDI learning model is carried out by having scientific work in cooperative groups. This learning model is able to close the gap between students who have high achievement and low achievement, and to reduce the negative impact of competitive learning (Sahin, 2010; Gunawan et.al., 2020). The students' interaction in expert group (jigsaw) are related to the discovery activities in finding concepts or facts through the stages of scientific work. In the home group (jigsaw), social interactions are presented in discussion and presentation activities to create a complete understanding of concepts about the Qur'an tafsir.

The results of observations, interviews, and questionnaire show that JIDI learning model is more fun and not to be monotonous/boring. The learning process is more directed to obtain the learning objectives. This model creates more pleasurable and active situation in which students learn to interact in groups to find, cooperate, and share knowledge. This model drives students to have intact understanding through group discussion, so there is no different interpretation about the learning materials.

The literature review of studies on classroom learning reveals that the implementation of JIDI (Jigsaw Discovery) learning model is more effective (Leyva \& Riu, 2016; Yemi et. al., 2018; Subiyantari et. al., 2019(Jigsaw); Rambe et. al., 2018; Wardono et.al., 2020; Winarni et.al., 2020; Gunawan \& Lestari, 2020 (Discovery Learning)). A study by Leung et.al. (2018) has collaborated the discovery learning with the geogebra model assistant, it shows that learning activities are effective and fun. Research by Suryanti et.al. (2020) reveals that the discovery learning that is collaborated with the problem solving shows an increase in the students' ability and understanding to master the concept of materials very well and optimally. Previous scientific study conducted by Darmuki \& Hariyadi (2019) in classroom learning using Jigsaw cooperative learning model. It can improve students' learning outcomes. Learning strategies, which include learning models and methods that are implemented by the lecturers, will influence the success of learning objectives. The lecturer's ability in implementing learning model and method will make it easier for students to receive learning materials (Darmuki et al., 2018).

Compared to previous researchs, this study on JIDI learning model makes students to be curious and motivates them to find solution of problems given. It is in line with Rachma(2017) and Dedonno (2016) who state that JIDI learning model influences on students' motivation. The implementation of this model which is in forms of students' 
groupworks can improve their motivation than learning individually. Different findings is found in the study conducted by Martaida et.al. (2017) and Ritonga \& Ruslan (2017). It shows that groupwork is useless in the JIDI learning model, so teacher has to motivate students by guiding them.

The weakness of this study was found in the classroom learning. The commitment of lecturer when implemented JIDI learning model which used jigsaw learning more dominant than discovery learning. Moreover, in the learning process, the students were lack of competitive situation. There were some students who dominated the learning activities, even though all students were active in the leaning process. The strength of this study lied in the social interaction and students' need in creating a complete understanding about Qur'an tafsir. It made the students' learning outcomes were improved. The implementation of JIDI learning model in this study is proven by its application in learning Qur'an tafsir. The students find it is easier to understand the interpretation of the Qur'an, so that their competence about Qur'an tafsir is better. It is suggested for the future research to carry out a study on the use of JIDI learning model in the primary school, middle school, and university with different field of study. Moreover, the impact of JIDI learning model on another aspects of education need to be examined. The implication of this study is that learning using JIDI model needs a long time, so it is suitable for the learning material with time allotment of eight meetings.

\section{CONCLUSION}

The results of this study are very important for the learning of Qur'an tafsir. JIDI learning model has a positive influence on students' success and the learning effectiveness in the class. Based on the findings and discussion, the conclusion of this study is: JIDI learning model is more effective than conventional one as it is able to improve students' ability in Qur'an tafsir at the Islamic Communication \& Broadcasting Department. The implementation of JIDI learning model in this study is proven by its application in learning Qur'an tafsir. The students find it is easier to understand the interpretation of the Qur'an, so that their competence about Qur'an tafsir is better. This study provides an overview to the lecturers, students, and academicians about the success of improving the quality of process and learning outcomes using the JIDI learning model. This success is inseparable from the influence of lecturers, students, model, and appropriate learning methods that produce good learning process and outcomes, as well as other factors that influence each other.

The implementation of JIDI learning model in forms of groupwork can increase motivation, rather than learning individually. This learning model also create relaxed and fun classroom situation, so there is a good relationship between students and lecturer. In this condition, the students are easier to learn maximally. Further studies are needed to test the practicality and effectiveness of JIDI learning model compared to another model to determine students' learning outcomes in the course of Qur'an tafsir. It is suggested for future researchers to carry out research using JIDI learning models on other materials and investigate the impact of this learning model on another learning aspects beyond the learning outcomes and social interactions. 


\section{REFERENCES}

Arifmiboy. (2018). Perbedaan Individu dan Perkembangan Kognitif Anak Serta Implikasinya Terhadap Pembelajaran. Journal Polingua, 3(2), 106-115. https://doi.org/10.30630/polingua.v3i2.26.

Creswell, Jhon W. (2013). Qualitative Inquary \& Research Design Choosing Among Five Approaches Third Edition, Sage Publications, Inc.

Darmuki, A., Andayani, Joko Nurkamto, Kundharu Saddhono. (2017). Evaluating Information-Processing-Based Learning Cooperative Model on Speaking Skill Course. Journal of Language Teaching and Reasearch, 8(1), 44-51. https://doi.org/10.17507/jltr.0801.06.

Darmuki, A., Andayani, Joko Nurkamto, Kundharu Saddhono. (2018). The Development and Evaluation of Speaking Learning Model by Cooperative Approach. International Journal of Instruction, $11(2), \quad 115-128$. https://doi.org/10.12973/iji.2018.1129a.

Darmuki, A. \& Ahmad Hariyadi. (2019). Eksperimentasi Model Pembelajaran Jucama Ditinjau Dari Gaya Belajar Terhadap Prestasi Belajar Mahasiswa Mata Kuliah Berbicara Di Prodi PBSI IKIP PGRI Bojonegoro. Kredo, 3(1), 62-72. https://doi.org / 10.24176/kredo.v3i1.4021.

Darmuki, A. \& Hidayati N.A. (2019). An Investigation of The Cooperative Learning Using Audio Visual Media in Speaking Skill Subject. ICSTI, 121-126. https://eudl.eu/doi/10.4108/eai.19-10-2018.2282555.

Darmuki, A. \& Hidayati, N.A. (2019). Peningkatan Kemampuan Berbicara Menggunakan Metode Kooperatif Tipe NHT pada Mahasiswa Tingkat I-A Prodi PBSI IKIP PGRI Bojonegoro Tahun Akademik 2018/2019. Jurnal Pendidikan Edutama,. 6(2), 9-18. https://ejurnal.ikippgribojonegoro.ac.id/index.php/JPE/article/view/453/0.

Darmuki, A., Ahmad Hariyadi. (2019). Peningkatan Keterampilan Berbicara Menggunakan Metode Kooperatif Tipe Jigsaw pada Mahasiswa PBSI Tingkat IB IKIP PGRI Bojonegoro Tahun Akademik 2018/2019. Kredo, 2(2), 256-267. https://doi.org/10.24176/kredo.v2i2.3343.

Darmuki, A., Andayani, Joko Nurkamto, Kundharu Saddhono. (2017). Cooperative, Synectics, and CTL Learning Models Toward Speaking Ability Viewd from Students Motivation. Proceeding International Conference on Intellectuals'Global Responsibility (ASSEHR), 125, 75-79.

Dedonno, M. A. (2016). The influence of IQ on pure discovery and guided discovery learning of a complex real-world task. Learning and Individual Differences, 49, 11-16. https://doi.org/10.1016/j.lindif.2016.05.023.

Evcim, H., \& İpek, Ö. F. (2013). Effects of jigsaw ii on academic achievement in english prep classes. Procedia - Social and Behavioral Sciences, 70, 1651-1659. https://doi.org/10.1016/j.sbspro.2013.01.236. 
Fraenkel, Jack R. And Norman E. Wallen. (2018). How to Design and Evaluate Research in Education. New York: McGraw-Hill Companies

Gunawan, Kosim, \& Lestari, P. A. S. (2020). Instructional Materials for Discovery Learning with Cognitive Conflict Approach to Improve Vocational Students' Achievement. International Journal of Instruction, 13(3), 433-444. https://doi.org/10.29333/iji.2020.13330a.

Hartini, L., Zainuddin., \& Miriam, S. (2018). Pengembangan Perangkat Pembelajaran Beorientasi Keterampilan Proses Sains Menggunakan Model Inquiry Discovery Learning Terbimbing. Berkala Ilmiah Pendidikan Fisika, 6(1), 6982. http://dx.doi.org/10.20527/bipf.v6i1.4448.

Hoerunnisa D., Neneng \& Suherdi. (2017).“The Effectiveness of Jigsaw II Model in Improving Students' Understanding of Citizenship Education,” J. English Educ., 5(1), 1-12. https://ejournal.upi.edu/index.php/L-E/article/view/9895

In'am, A., \& Hajar, S. (2017). Learning geometry through discovery learning using a scientific approach. International Journal of Instruction, 10(1), 55-70. https://doi.org/10.12973/iji.2017.1014a.

Indiastuti, F. (2016). Pengembangan Perangkat Model Discovery Learning Berpendekatan Saintifik untuk Meningkatkan Berpikir Kreatif dan rasa Ingin Tahu. Jurnal Pendidikan Matematika RAFA, 2(1), 41-55. http://jurnal.radenfatah.ac.id/index.php/jpmrafa/article/view/1240.

Kistner, S., Vollmeyer, R., Burns, B. D., \& Kortenkamp, U. (2016). Model development in scientific discovery learning with a computer-based physics task. Computers in Human Behavior, 59, 446-455. https://doi.org/10.1016/j.chb.2016.02.041.

Leung, A. W., Hasratuddin., \& Syahputra, H. (2018). Development of learning devices based on discovery learning assisted geogebra models to improve self-regulated learning of students at SMP Negeri 1 Stabat. American Journal of Educational Research, 6(12), 1646-1653. https://doi.org/doi: 10.12691/education-6-12-9.

Leyva-Moral, J. M., \& Riu Camps, M. (2016). Teaching research methods in nursing using aronson's jigsaw technique. a cross-sectional survey of student satisfaction. Nurse Education Today, 40, 78-83. https://doi.org/10.1016/j.nedt.2016.02.017.

Lukman, F. (2018)."Digital Hermeneutics and A New Face of The Qur`an Commentary: The Qur'an in Indonesian's Facebook", Al-Jami'ah: Journal of Islamic Studies, 56(1), 95-120. https://doi.org/10.14421/ajis.2018.561.95-120.

Lukman, F. (2016)."Tafsir Sosial Media Di Indonesia," Nun : Jurnal Studi Alquran Dan Tafsir Di Nusantara, 2(2), 117-139. https://doi.org/10.32495/nun.v2i2.59.

Lukman, F. (2016). Studi Kritis atas Teori Tarjamah Alquran dalam Ulum Alquran”, AlA'raf : Jurnal Pemikiran Islam dan Filsafat, 13(2), 167-90. https://doi.org /10.22515/ajpif.v13i2.262. 
Martaida, T., Bukit, N., \& Ginting, E. M. (2017). The effect of discovery learning model on student's critical thinking and cognitive ability in junior high school. IOSRJRME, 7(6),1-8. https://doi.org/10.22611/jpf.v7i2.8951.

Muhammad, WI. (2017). “Facebook Sebagai Media BaruTafsir Al-Qur'an Di Indonesia: Studi Atas Penafsiran Alquran Salman Harun," Maghza: Jurnal Ilmu Al-Qur'an dan Tafsir, 2(2) 69-80. https://doi.org/10.24090/ maghza.v2i2.1570.

Naguib, S. (2019). The Hermeneutics of Miracle: Evolution Eloquence, and the Critique of Scientific Exegesis in the Literary School of Tafsir. Journal of Qur'anic Studies, 21(3), 57-88. https://doi.org/10.3366/jqs.2019.0399.

Nuralvi, A. (2018). “Metodologi Penafsiran Al-Qur'an Dalam Website Almanhaj.or.Id Dan Website Nadirhosen.Net” Diploma: UIN Sunan Gunung Djati Bandung.

Nurdiana, H., Pujiastuti, E., \& Sugiman, S. (2018). Kemampuan Komunikasi Matematis Ditinjau dari Self-Efficacy Menggunakan Model Discovery Learning Terintegrasi Pemberian Motivasi. Prisma, Prosiding Seminar Nasional Matematika, 1, 120-129.

Nuryakin \& Riandi. (2017). Improving middle school students' critical thinking skills through reading infusion-loaded discovery learning model in the science instruction. Journal of Physics: Conference Series, 812, 1-6. https://iopscience.iop.org/article/10.1088/1742-6596/812/1/012003.

Ogunnaike O. (2018). In The Gardens with Ibrahim: An Evaluation of Fi Riyad al tafsir by Shaykh Ibrahim Niasse, a Contemporary, Traditional Tafsir. Journal of Qur'anic Studies, 20(1), 28-46. https://www.euppublishing.com/doi/abs/10.3366/jqs.2018.0319.

Putri, A., Roza Y., \& Maimunah. (2020). Development of Learning Tools with the Discovery Learning Model to Improve the Critical Thinking Ability of Mathematics. Journal of Educational Sciences, 4(1), 83-92. http://dx.doi.org/10.31258/jes.4.1.p.8392.

Rachmah, D. N. (2017). Effects of Jigsaw Learning Method on Students SelfEfficacy and Motivation to Learn. A Journal of Education, Health and Community Psychology, 6(3), 1-9. http://dx.doi.org/10.12928/jehcp.v6i3.8314.

Rahmadani, E., Fauzi, M. A., \& Karnasih, I. (2017). Pengembangan Perangkat Pembelajaran Berbasis Model Discovery Learning Untuk Meningkatkan Kemampuan Pemahaman Konsep Dan Diposisi Matematis Siswa Berbantuan Geoboard. Jurnal Paradikma, 10(2), 106-117. https://doi.org/10.24114/paradikma.v10i2.8692.

Rambe, J. A., Sinaga, B., \& Yusnadi. (2018). The development of learning devices based on discovery learning to improve mathematical creative thinking ability of student class v at SD Negeri 060827 Medan Amplas. Journal of Education and Practice, 9(9), 72-79. https://www.iiste.org/Journals/index.php/JEP/article/view/41739.

Ritonga M. \& Ruslan D. (2017).“The Effect of Jigsaw Learning Strategy to Students ' Civic Learning Outcomes in Grade V SDN 107403 Cinta Rakyat Academic Year 2016 / 
2017,” IOSR J. Res. Method Educ., 7(5), 64-72. https://doi.org/10.9790/7388-0705056472.

Saeed S. (2019). The Shahin Affair and The Evolution of Usul Al-Tafsir. Journal of Qur'anic Studies, 21(3), 114-144. https://www.euppublishing.com/doi/abs/10.3366/jqs.2019.0401.

Saputra, M. D., Joyoatmojo, S., Wardani, D. K., \& Sangka, K. B. (2019). Developing Critical-Thinking Skills through the Collaboration of Jigsaw Model with Problem-Based Learning Model. International Journal of Instruction, 12(1), 1077-1094. https://doi.org/10.29333/iji.2019.12169a.

Şahin, A. (2010). Effects of jigsaw II technique on academic achievement and attitudes to written expression course. Educational Research and Reviews, 5(12), 777-787. https://academicjournals.org/journal/ERR/article-full-text-pdf/33E2E094215.

Sanjaya, W. (2006). Strategi Pembelajaran. Jakarta: Kencana Prenada Media Group.

Shabana A. (2019). In Pursuit of Consonance: Science and Religion in Modern Works of Tafsir. Journal of Qur'anic Studies, 21(3), 7-31. https://www.euppublishing.com/doi/abs/10.3366/jqs.2019.0397.

Sugiyono. (2011). Metode penelitian kuantitatif, kualitatif, dan $R \& D$. Bandung: Alfabeta.

Subiyantari, AR., Muslim S., \& Rahmadyanti E. (2019) Effectiveness of Jigsaw Cooperative Learning Models in Lessons of the Basics of Building Construction on Students Learning 'Outcomes Viewed from Critical Thinking Skills. International Journal for Educational and Vocational Studies, 1(7), 691-696. https://doi.org/10.29103/ijevs.v1i7.1653.

Suryanti, Widodo, W., \& Budijastuti, W. (2020). Guided Discovery Problem-Posing: An Attempt to Improve Science Process Skills in Elementary School. International Journal of Instruction, 13(3), 75-88. https://doi.org/10.29333/iji.2020.1336a.

Şengül, S., \& Katranci, Y. (2014). Effects of jigsaw technique on mathematics selfefficacy perceptions of seventh grade primary school students. Procedia - Social and Behavioral Sciences, 116, 333-338. https://doi.org/10.1016/j.sbspro.2014.01.217

Trianto. (2018). Mendesain Model Pembelajaran Inovatif - Progresif. Jakarta: Kharisma Putra Grafika.

Van Dat, T. (2016). The Effects of Jigsaw Learning on Students' Knowledge Retention in Vietnamese Higher Education. International Journal of Higher Education, 5(2), 236242. https://doi.org/10.5430/ijhe.v5n2p236.

Wardono, Rochmad, Uswatun, K., \& Mariani, S. (2020). Comparison between Generative Learning and Discovery Learning in Improving Written Mathematical Communication Ability. International Journal of Instruction, 13(3), 729-744. https://doi.org/10.29333/iji.2020.13349a. 
Wilson. J. A., Pegram, A. H., Battise, D.M., Robinson, A.H. (2017). Traditional Lecture Versus Jigsaw Learning Method for Teaching Medication Therapy Management (MTM) Core Elements. A Journal of Currents in Pharmacy Teaching and Learning, 9(6), 11511159. https://doi.org/10.1016/j.cptl.2017.07.028.

Winarni, E. W., Hambali, D., \& Purwandari, E. P. (2020). Analysis of Language and Scientific Literacy Skills for 4th Grade Elementary School Students through Discovery Learning and ICT Media. International Journal of Instruction, 13(2), 213-222. https://doi.org/10.29333/iji.2020.13215a.

Yemi, T. M., Binti, N., \& Azid, H. (2018). Effect of jigsaw strategy of cooperative learning on mathematics achievement among secondary school students, Eur. J. Educ. Stud, 4(2), 51-61. http://dx.doi.org/10.46827/ejes.v0i0.1428. 